Biol. Neonat. 1968;13:I-IV

\title{
Contents, Vol. 13, 1968
}

\section{Index}

Alexander, G. and Mills, S. C.: Free Fatty Acids and Glucose in the Plasma of

Newly Born Lambs: Effects of Environmental Temperature

Barnett, R.: vide Cassady, G

Boréus, L. O.: vide McMurphy, D. M

Browning, Ann B.: vide Czajka, D. M

Campbell, D.: Motor Activity in a Group of Newborn Babies

Cao, A.; Virgiliis, de S. and Falorni, A.: The Ontogeny of Creatin-Kinase Isozymes $\quad 375$

Capková, A. and Jirásek, J.E.: Glycogen Reserves in Organs of Human Foe tuses in the First Half of Pregnancy 129

Carrington, E.R.: vide Urbach, J.R

Carr, D. H.: vide Singh, R. P

Cassady, G. and Barnett, R.: Amniotic Fluid Electrolytes and Perinatal Outcome 155

Cavoto, C. M.: vide Urbach, J.R

Craig, John M.: Observations on the Mechanisms of Development of Congenital

Anomalies in the Rat Produced by Anti-Rat Kidney Sera 361

Csögör, S.; Csutak, J. and Pressler, A.: Modifications of Albumin Transport

Capacity in Pregnant Women and Newborn Infants 211

Csutak, J.: vide Csögör, $\mathrm{S}$

Czajka, D.M.; Miller, S.A. and Browning, Ann B.: Protein Synthesis in

Neonatal Rat Pups Maintained Artificially on a Low Protein Diet 291

DeSa, D.J.: Respiratory Distress Accompanied by Changes in the Pulmonary

Water Content and Alveolar Lining Layer in Newborn Rabbits Recovering

from Oxygen Lack 271

Falorni, A.: vide Cao, A

Formentin, P. A.: vide Rubaltelli, F. F

Friel, M.Y.: vide Urbach, J.R

Fox, S.: vide Ostwald, P. F

Giacanelli, M.; Reniers, J. and Martin, L.: Morphology and Histology of

Foetal Muscles 281

Hahn, P.: vide Novak, $M$

Hambraeus, L. and Wranne, L.: The Plasma Phenylalanine Level in Newborn

Infants of Normal and Low Birth Weights Fed on Human Milk 315

Hathaway, W.E. and Henderson, Barbara J.: Effect of Hypoxia on Coagula

tion Factors in the Newborn Dog 26

Henderson, Barbara J.: vide Hathaway, W.E

Heringová, A.; Koldovský, O.; Yaffe, S.J. and Jirsová, V.: Sulfatase Activity

of the Jejunum and Ileum of Rats during Postnatal Development 
Heringová, A.: vide Jirsová, V

Hommes, F.A. and Wilmink, C.W.: Developmental Changes of Glycolytic

Enzymes in Rat Brain, Liver and Skeletal Muscle 181

Hommes, F. A.: vide Vos, de M. A

Jirásek, J. E.: vide Capková, A

Index

Jirsová, V.; Koldovský, O.; Heringová, A.; Uher, J. and Jodl, J.: Develop

ment of Invertase Activity in the Intestines of Human Fetuses, Appearance

of Jejunoileal Differences 143

Jirsová, V.: vide Heringová, A

Jodl, J.: vide Jirsová, V

Karlsson, B.W.: Lactic and Malic Dehydrogenase Activities and Isoenzyme

Patterns in Blood Sera of Developing Neonatal Piglets 34

Koldovský, O.: vide Heringová, A

Koldovský, O.: vide Jirsová, V

Lambert, R. L.: vide Urbach, J. R

Larroche, J. C.: Necrose cérébrale massive chez le nouveau-né. Ses rapports avec

la maturation, son expression clinique et bioélectrique $\quad 340$

Laskowska, H.: vide Szamborski, J

Lausmann, S.: vide Sabata, V

Loveland, M. W.: vide Urbach, J. R

Martin, L.: vide Giacanelli, $\mathrm{M}$

Melichar, V.: vide Novak, M

McMurphy, D.M. and Boréus, L.O.: Pharmacology of the Human Fetus

Adrenergic Receptor Function in the Small Intestine 325

Miller, S.A.: vide Czajka, D.M

Mills, S. C.: vide Alexander, G

Mrosovsky, N. and Rowlatt, Ursula: Changes in the Microstructure of Brown

Fat at Birth in the Human Infant 230

Murdock, A.I. and Swyer, P.R.: The Contribution to Venous Admixture by

Shunting through the Ductus Arteriosus in Infants with the Respiratory

Distress Syndrom of the Newborn 194

Nijs Bıк, de H.: vide Tjoa, G. T

Novak, M.; Melichar, V. and Hahn, P.: Changes in the Reactivity of Human

Adipose Tissue in vitro to Epinephrine and Norepinephrine during Post

natal Development 175

Ojtwald, P.F.; Phibbs, R. and Fox, S.: Diagnostic Use of Infant Cry 68

Phibbs, R.: vide Ostwald, P. F

Pihlaja, T.; Välimäki, I. and Yrjänä, T.: Effect of Peroral Ascorbic Acid on

Blood Methemoglobin of Newborn Infants 62

Pressler, A.: vide Csögör, S

Reniers, J.: vide Giacanelli, $M$

Rojas, J.F.: vide Urbach, J.R

Rossdale, P. D.: Blood Gas Tensions and $\mathrm{pH}$ Values in the Normal Thoroughbred

Foal at Birth and in the Following $42 \mathrm{~h}$ 
Roux, J. F.: Glyceride Fatty Acid Synthesis by Liver Homogenates of the Develop ing Rabbit 109

Rowlatt, Ursula : vide Mrosovsky, N. ..,

Rubaltelli, F.F. and Formentin, P. A.: Ammonia Nitrogen, Urea and Uric Acid

Blood Levels in the Mother and in Both Umbilical Vessels at Delivery... 147

Sabata, V.; Wolf, H. and Lausmann, S.: The Role of Free Fatty Acids, Glycerol, Ketone Bodies and Glucose in the Energy Metabolism of the Mother and

Fetus during Delivery 7

Schopman, W.: vide Tjoa, G. T

Singh, R.P. and Carr, D.H.: Congenital Anomalies in Embryos with Normal

Chromosomes 121

Smith, C.H.: Regulation of Malate Dehydrogenase in the Liver of Newborn

Rabbits Maintained by a Convenient New Technique of Artificial Feeding 219

Swyer, P.R.: vide Murdock, A.I

Index

Szamborski, J. and Laskowska, H.: Some Observations on the Developmental

Histology of the Human Foetal Uterus 298

Tin, M.D.: vide Urbach, J.R

Tjoa, G.T.; Nijs Bıк, de H. and Schopman, W.: Diabetes Mellitus in a 2 Month

Old Female Infant 113

Uher, J.: vide Jirsová, V

Urbach, J.R.; Carrington, E.R.; Friel, M.Y.; Rojas, J.F.; Zweizig, H.L.;

Loveland, M.W.; Cavoto, CM.; Tin, M.D. and Lambert, R.L.:

Characteristics of Fetal Heart Sounds and Murmurs in the Second Half of

Gestation $\quad 90$

Välimäki, I.: vide Pihlaja, T

Virgiliis, de S. : vide Cao, A

Vos, de M.A.; Wilmink, C.W. and Hommes, F.A.: Development of some Mito-

chondrial Oxidase Systems of Rat Liver 83

Wilmink, C. W.: vide Hommes, F. A

Wilmink, C. W.: vide Vos, de M. A

Wolf, H.: vide Sabata, V

Wranne, L.: vide Hambraeus, L

Yaffe, S. J.: vide Heringová, A

Yrjänä, T.: vide Pihlaja, T

Zweizig, H.L.: vide Urbach, J.R

Book Reviews 254

All rights, including that of translation into other languages, reserved. Photomechanic reproduction (photocopy, microcopy) of this volume or parts thereof without special permission of the publishers is prohibited

(C)

Copyright 1968 by S.Karger AG, Basel

Printed in Switzerland by Buchdruckerei Fritz Pochon-Jent AG, Bern

Cliches: Aberegg-Steiner, Bern 